\title{
ATTITUDES TOWARDS PURCHASING FROM FOREIGN APPAREL RETAILERS: THE EFFECTS OF AGE AND FOREIGN COUNTRY VISITS
}

\author{
Assist.Prof.Dr. Burcu ÍLTER, Dokuz Eylül University, Faculty of Business, \\ Department of Business Administration, burcu.ilter@deu.edu.tr \\ Res.Assist. Bilge AYKOL, Dokuz Eylül University, Faculty of Business, \\ Department of Business Administration, bilge.aykol@deu.edu.tr \\ Res.Assist.Özge ÖZGEN, Dokuz Eylül University, Faculty of Business, \\ Department of Business Administration, ozge.ozgen@deu.edu.tr
}

\begin{abstract}
Turkey has become an attraction centerfor foreign retailers with its huge population. Clothing is one of the most important retail sectors in Turkey. The aim of this study is to explore the attitudes of consumers towards purchasing from foreign apparel retailers. Besides, the relationships between these attitudes and age and foreign country visits are investigated. The study was conducted in Izmir in three main central business districts. Data were collected with a questionnaire, which was applied to more than 500 individuals in December 2007. Results show that these retailers had favorable attitude scores related to style and size, but unfavorable attitude scores related to price and popular brand names. Age was found to be negatively correlated with attitudes. Having visited foreign countries created differences on attitudes.
\end{abstract}

Key Words: International retailing, attitude, apparel retailing

\section{INTRODUCTION}

Increasing competition in the retail markets of developed countries is enhancing the interests of multinational apparel firms in developing countries (Dickson, Lennon, Montalto, Shen \& Zhang, 2004). As clothing has become internationalized, consumers are progressively more getting in touch with imported products (Kawabata \& Rabolt, 1999). 
Turkey has become an attraction center for foreign retailers, which can be attributed to its huge population. Big cities in particular have been the target of international retailers. About $35 \%$ of retailers are based in four biggest cities of Turkey (Euromonitor, 2004). Similar to developments in international retailing throughout the world, since the late 1980s, foreign retailers have entered into Turkey (Tokatlı \& Boyacl, 1998). Although there are many Turkish apparel retailers, foreign textile products draw attention of Turkish consumers and an important opportunity for foreign apparel retailers arises. Clothing has been the third most important sub-sector of retail business with US $\$ 5.3$ billion retail sales in Turkey in 2002 (Euromonitor, 2004).

The business environment of fashion sector has been constantly changing and the development and implementation of marketing strategy has a critical importance for the apparel firms to lead their growths or long-term survival (Moore \& Fairhurst, 2003). In this sense, market and customer differences constitute an important place in international marketing. Countries may differ in many characteristics, ranging from demographics, culture, and geography to economics, which could create differences in consumer behavior. Thus, the attitude of residents in different countries towards international firms is also a characteristic which may change from one country to another. This characteristic may affect the strategies and performance of international retailers and thus should be considered by these firms planning to enter to different countries.

The aim of this study is to explore the attitudes towards purchasing from foreign apparel retailers. Article starts with a literature review focusing on international retailing in Turkey and attitudes towards purchasing from foreign apparel retailers. Age and visits to foreign countries, which might have an influence on the attitudes of individuals towards buying from foreign apparel retailers, are also discussed. Then, the research questions in this context are presented. This part is followed by the findings of an empirical study conducted in Izmir. Finally, conclusions and recommendations are discussed.

\section{LITERATURE REVIEW}

\subsection{International Retailing in Turkey}

Since the beginning of the 1980 s, global retail community has seen an expansion of international retail activities (Vida \& Fairhurst, 1998). Parallel to these changes in the world, since the late 1980s, foreign retailers have entered into Turkey by associating with Turkish firms via licensing agreements or joint ventures. At the same time period, in the clothing sector, many firms entered Turkey by opening their own stores or through their designer products without opening stores like Benetton (1986), Sisley (1991), Levi's (1989) and Mothercare (1988) among others (Tokatli \& Boyaci, 1998). It should be noted that 1990s witnessed many changes and developments in retailing in Turkey 
and foreign retailers have constituted a significant part of modern retailers. Foreign capital flow into retailing sector has been increasing since 1990 with French, British and US being the leading investors (Tek \& Demirci Orel, 2006). Currently, it can be observed that foreign apparel retailers are occupying a considerable part in shopping malls in big cities. Even sometimes, their presence is presented in a way to draw attention when new shopping malls are opened.

Big cities offered considerable market opportunities and attracted foreign retailers, probably because the largest part of the population is located in those cities. Izmir, not being an exception, has also been one of the attraction centers of foreign retailers. It should be noted that until mid 1990s, the retail structure of İmir mainly comprised small-scale traditional retailers. The mid 1990s introduced some major large-scale retail developments in the city. Currently, Izmir is said to have a dual retail structure: large-scale western type and traditional small-scale retail outlets (Kompil \& Çelik, 2006). The foreign apparel retailers are found in Izmir mostly in shopping malls and in high-end central business districts. Hence, one can fairly say that they are located in places where western-type modern retailers are concentrated.

\subsection{Attitudes towards Purchasing from Foreign Apparel Retailers}

Countries may differ in many characteristics, which should be the concern of international retailers planning to enter into different countries. Marketers are strongly recommended to evaluate new target markets intensively, particularly if these are distant and unfamiliar (White \& Absher, 2007). De Mooji and Hofstede (2002) concluded that retailers might face serious losses if they expand their operations to countries with different cultural values.

Attitude is "a mental and neural state of readiness, organized through experience, exerting a directive or dynamic influence upon the individual's response to all objects and situations with which it is related" (Allport, 1967, p.8). Attitude describes the way people are inclined to react to a stimulus (Udell, 1971). Consumers express preference or lack of preference for stores, brands, advertisements and other marketing stimuli by reflecting a favorable or unfavorable attitude. In this sense, consumers with a favorable attitude toward a store will most likely select the store and buy its products, but consumers with unfavorable attitudes will not select the store and not purchase the products there (Moye \& Kincade, 1999: 58-59). Hence, attitudes of consumers towards international retailers are believed to be an important factor which should be considered by international retailers planning to enter to different countries.

Fishbein (1967) developed an attitude model in order to have a better understanding of the relations between attitude, intention and behavior. Intention can be described as a person's subjective probability that he will perform some behavior and it is the conative component of attitude (Fishbein \& 
Ajzen, 1975). It has usually been assumed that this conative component is related to the attitude's affective component. This conceptualization has directed the assumption of a strong relation between attitudes and intention (Fishbein \& Ajzen, 1975). In addition to this, one of the main focuses of the researchers is to figure out the relation between attitude, intention and a person's actual behavior. Based on the idea of consistency, attitudes toward an object are generally anticipated to be related to behaviors toward the object (Peter \& Olson, 1987). Fishbein $(1980,152)$ states that "most market researchers believe, and operate under the assumption, that the more favorable a person's attitude toward a given product (or brand), the more likely the person is to buy or use that product (or brand)."

Fishbein (1967), in his multi-attribute attitude model, explained that two major components determine the attitude toward performing a behavior. According to the theory, a person's attitude is a function of "his beliefs and the implicit evaluative responses associated with those beliefs".

Fishbein attitude model has been used in retailing literature. For instance, Evans et al. (1996) and Vijayasarathy and Jones (2000) used the model to measure attitudes in malls and internet shopping, respectively. Additionally, a review of the literature revealed that there were a number of studies regarding the attitudes toward domestic and foreign products. For example, Beaudoin et al. (1998) analyzed the fashion leaders and followers attitude toward imported and domestic apparel and they found that fashion leaders had overall more positive attitude toward imported apparel than domestic apparel. Wang and Heitmeyer (2006) compared the attitude toward US versus Taiwan made apparel based on demographic factors and self-concept variables. Phau and Leng (2008) determined the differences between the attitudes of status and non-status seeking Australian teenagers toward buying domestic and foreign (i.e. Italy, Japan, China) luxury brand apparel. On the other hand, although there were many studies regarding attitudes toward domestic and imported products in the literature, research studies, which examine the attitudes toward buying from domestic or imported apparel retailers, are limited.

In order to apply the model, first of all, attributes, which are considered when purchasing clothing from a foreign retailer, should be identified. In the existing literature, the apparel store attributes were examined mostly within the context of domestic environments. On the other hand, in the international context, the attributes important in selecting imported apparel were studied, rather than apparel retailers.

Consumers evaluate stores while planning a shopping trip as well as during their shopping. (e.g. Lumpkin, 1985; Stone 1954). In these evaluations they use some criteria which might be addressed as attributes. Store attributes influence consumer decisions to patronize or shop at particular retail stores (Lindquist, 1974/75). For example in the apparel shopping context, Paulins and Geistfeld (2003: 375) employed 14 store attributes, which were advertising, appeal of 
clothing in the store, displays, dressing rooms, ease of location of merchandise, layaway plan, outside appearance, parking, prices, rest rooms, return policy, sales assistance, shopping hours and store location. The studies regarding imported apparel used various attributes. In the context of imported apparel, Wang and Heitmeyer (2006) investigated whether or not consumer attitudes toward domestic- vs. US-made apparel differ among consumers in Taiwan. For apparel attributes, they used price, fit, ease of care, care instructions label, color, apparel fiber content, quality, fashionableness, comfort, attractiveness, brand name, suitability to you, and appropriateness for occasion. However, it would not be proper to use imported apparel attributes for our study, because many foreign retailers, at least in Turkey, sell those apparel, which are made in Turkey. The only study which explicitly examined international apparel retailers was the one by Hyllegard et al. (2005), who examined consumers'store patronage and apparel purchase behavior, acceptance of US apparel brands, perceptions of retailers' products and services, and perceptions of the impact of foreign retailers on local communities in Spain.

$R Q$ 1: What are the attitudes towards purchasing from foreign apparel retailers?

\subsection{Influence of Age on Attitudes}

Different consumers respond differently to the same shopping atmosphere and/or to the same product (Yalch and Spangenberg, 1993; as cited in Scarpi, 2006). Researchers have found that consumer demographics may influence the importance placed on the store attributes (Lumpkin, 1984; Pessemier, 1980). Age being one of the most important demographic factors also has an influence on the decisions of people. Research on elderly consumers shows that specific store attributes becomes more important for this age group. The reason might be their special needs determining store patronage (Chowdhary, 1989; Lumpkin and Greenberg, 1982; Lumpkin et al., 1985; Mason and Bearden, 1978; Visvabharathy and Rink, 1985). Younger consumers seemed most favorably inclined to purchase foreign made or foreign brand apparel since they were more influenced by fashion and likely to try new products and famous brand names, considered symbolism important, and they were less sensitive to higher prices. (Anderson \& He, 1998; Ariga et. Al, 1997; Landry, 1998; Schmitt, 1997; Zhang et al., 2002; as cited in Dickson et.al, 2004). Beaudoin et al. (1998) found that young [fashion leaders] had an overall more positive attitude toward imported apparel than domestic apparel. In a study conducted in Taiwan, age was found to be significantly related to consumers' attitudes toward Taiwan (domestic)- and US-made apparel. The oldest group had the highest attitude scores toward US-made apparel, followed by the youngest group (Wang \& Heitmeyer, 2006).

$R Q$ 2: What will be the relationship between age and attitudes toward purchasing from foreign apparel retailers? 


\subsection{Influence of Visits to Foreign Countries}

A consumer's knowledge about a product's origin has been shown to have a significant effect on subsequent product evaluations (e.g. Peterson \& Jolibert, 1995; Bilkey \& Nes, 1982; Parameswaran \& Pisharodi, 1994; Piron, 2000). Trips to foreign countries might be one way that consumer gain familiarity with international brands. Levitt (1983) argued that technology, which has "proleterianized" communication, transport and travel drove the world toward a merging commonality; that was leading to globalization of markets for standardized consumer products and the world's needs and wants had been homogenized into best quality products and reliability at the lowest price. Consistency in the image projected to customers might increase sales for mobile customers like tourists and traveling businessmen among others (Buzzell, 1968). It may also indicate that exposure to foreign firms in foreign countries may have led to the familiarity with these firms before they entered Turkey. Thus, the third research question is:

RQ 3: Will foreign country visits create significant differences on the attitude, intention and behavior related to purchasing from foreign apparel retailers?

\section{METHODOLOGY}

Questionnaire was used as the instrument of collecting data. The first part of the questionnaire includedquestions about the attitudes towards purchasing from foreign apparel retailers. Fishbein's (1967) multi-attribute attitude model was used to measure and compare the attitudes toward behavior. As mentioned previously, this model is based on two major components, which determine the attitude toward performing a behavior: "a person's attitude is a function of his beliefs and the implicit evaluative responses associated with those beliefs". The estimation of attitude is calculated by using the following formula:

$$
\begin{aligned}
& A_{B}=\sum_{i=1}^{n} b_{i} e_{i} \\
& A_{b}=\text { Attitudes toward behavior (purchasing from foreign apparel retailer) } \\
& \mathrm{b}_{\mathrm{i}}=\text { belief that performing behavior (purchasing from a foreign apparel } \\
& \text { retailer) will lead to certain attributes } \\
& \mathrm{e}_{\mathrm{i}}=\text { Evaluation of the importance of the attribute } \\
& \mathrm{i}=\text { Attributes }
\end{aligned}
$$

Overall, 12 attributes were evaluated. 10 of these attributes were adopted from the study of Hyllegard et al. (2005), who explicitly made a research on international apparel retailers. These attributes included quality of products, fashionability of products, product assortment, customer service, convenience of locations, number of payment options, organization of store layout, sales promotions, popular brand names, and price of products. Remaining two attributes, style and size, were added by the authors based on the literature. 
In order to find $e_{i}$, respondents evaluated these attributes on a 7-point importance scale, where 1 meant "not important at all" and 7 meant "very important". In measuring the beliefs $\left(b_{i}\right)$, respondents were asked about the consequences of purchasing from foreign apparel retailers. A 7-point scale was incorporated, where 1 represented "Strongly disagree" and 7 "Strongly agree". That means, respondents were asked to state the importance of an attribute e.g. fashionability for any clothing purchase. Then, in the belief scale, they stated the extent to which they agree that purchasing from a foreign apparel retailer would result in having this attribute (fashionability). Then, based on the formula, for each respondent, the overall attitude toward purchasing from foreign apparel retailers was calculated, by multiplying the evaluation score $\left(e_{i}\right)$, and the belief score $\left(b_{i}\right)$, and by summing the results for 12 attributes. The reliability of this scale was 0.902 .

In order to measure foreign country visits of respondents, they were asked whether they have ever visited a foreign country; using a nominal scale. Foreign language skills were asked by using a nominal scale, too. The respondents were asked whether they could speak a foreign language. The authors also asked the level of foreign language skills as introductory, intermediate and advanced levels. Yet, most of the respondents declared their level as intermediate, which did not allow an analysis for comparison. The final part of the questionnaire included the questions related to demographics of the respondents.

The questionnaire was applied on 507 individuals. 18 volunteer students of Marketing Strategies course conducted the questionnaire in three main central business districts of Izmir in the end of December 2007, when people were busy making New Year shopping. These districts included Konak, Alsancak and Karşıyaka. In each of these three districts, two days were arranged for conducting the questionnaire: one on a weekday and one on weekend. On each day, 3 students were ready to conduct the questionnaire. The questionnaire was applied to those people who accepted to participate in the questionnaire and the students were controlled by the authors.

\section{FINDINGS}

\subsection{Profile of the Respondents}

Table 1 demonstrates the demographic profile of the sample. Distribution of two sexes among respondents was nearly equal. It should be noted that age variable were grouped by the authors. The minimum age was 16 and the maximum age was 75 while the mean age was 30,34 . Most of the sample was between 21 and 40 age range $(n=327, \%=65,4)$. Most of the participants perceived themselves in the middle-income group $(n=352, \%=70,5)$. More than half of the participants had higher education $(n=292, \%=58,5)$ and most of the participants were single $(n=298 ; \%=59,5) .260(\%=52,6)$ of them had a job. 
About one fourth of the participants stated that they had visitedforeign countries.

\subsection{Attitudes towards Purchasing from Foreign Apparel Retailers}

The attitude model of Fishbein involves two scales; the scale used to evaluate attributes on importance scale and the scale used to measure beliefs about the consequences of purchasing from these retailers. Table 2 demonstrates the importance level attached to the various attributes considered when buying clothing. The most important attributes for the respondents turned out to be size, style, and quality respectively. The least important ones, on the other hand, are popular brand names, fashionability and store layout, respectively. Although these attributes had the lowest scores, it might be better to consider them as relatively less important compared to the rest of the attributes. They all have scores higher than four and since the measurement scale was between 1 and 7 , they cannot be considered as unimportant. The rest of the attributes had scores higher than five, which means they were also considered as quite important.

Table 1: Demographic Characteristics of Respondents

\begin{tabular}{|c|c|c|c|}
\hline & Demographics & $\mathrm{N}$ & $\%$ \\
\hline Age Groups & 20 and younger & 83 & 16,6 \\
\hline & $21-40$ & 327 & 65,4 \\
\hline & 41 and over & 90 & 18,0 \\
\hline & Total & 500 & 100 \\
\hline Gender & Female & 255 & 50.7 \\
\hline & Male & 248 & 49.3 \\
\hline & Total & 503 & 100 \\
\hline Perceived income & Low income & 42 & 8,4 \\
\hline group & Middle income & 352 & 70,5 \\
\hline & High income & 105 & 21,0 \\
\hline & Total & 499 & 100 \\
\hline & Primary education & 47 & 9.4 \\
\hline & High school & 160 & 32.1 \\
\hline Education & Higher education & 292 & 58,5 \\
\hline & Total & 499 & 100 \\
\hline & Married & 178 & 35,5 \\
\hline Marital ctatuc & Single & 298 & 59,5 \\
\hline Iviarıtal status & Divorced/Widowed & 25 & 5 \\
\hline & Total & 501 & 100 \\
\hline & Employed & 260 & 52,6 \\
\hline Employment status & Unemployed & 234 & 47,4 \\
\hline & Total & 494 & 100 \\
\hline Visit to foreign & Those who have visited & 133 & 27,1 \\
\hline countries & Those who have not visited & 357 & 72,9 \\
\hline & Total & 490 & 100 \\
\hline Being able to speak a & Those who can speak a foreign language & 342 & 68,3 \\
\hline foreign language & Those who cannot speak a foreign language & 159 & 31,7 \\
\hline & Total & 501 & 100 \\
\hline
\end{tabular}


Table 3 demonstrates the beliefs of respondents about the consequences of purchasing from a foreign apparel retailer regarding the considered attributes, which have been explained previously. As seen in Table 3, all of the attributes had scores lower than 5 . Thus we can say that respondents do not believe that purchasing from foreign apparel retailers would result in these attributes (e.g. having quality products, fashionable products etc.). Especially pricing and convenience of location factors, which had the lowest belief scores, seems far from satisfying the participants. This finding is important for international retailers because these two attributes had in fact been evaluated as important in purchasing a new apparel product. Size has the highest belief score followed by style and product assortment.

Table 2: Importance Levels of Attributes Considered in Purchasing New Clothing

\begin{tabular}{|l|r|r|r|}
\hline & N & Mean* & \multicolumn{1}{|c|}{$\begin{array}{c}\text { Std. } \\
\text { Deviation }\end{array}$} \\
\hline Quality of products & 506 & 6,0395 & 1,30590 \\
\hline Fashionability of products & 505 & 4,7287 & 1,80378 \\
\hline Style & 505 & 6,2554 & 1,17855 \\
\hline Size & 505 & 6,5287 &, 95725 \\
\hline Product assortment & 505 & 5,2198 & 1,56131 \\
\hline Customer service & 503 & 5,6123 & 1,55855 \\
\hline Number of payment options & 505 & 5,6238 & 1,61989 \\
\hline Organization of store layout & 501 & 4,8762 & 1,69843 \\
\hline Sales promotions & 500 & 5,3660 & 1,74532 \\
\hline Popular brand names & 502 & 4,0777 & 1,91014 \\
\hline Price of products & 505 & 5,9842 & 1,39007 \\
\hline Convenience of locations & 506 & 5,2233 & 1,68262 \\
\hline
\end{tabular}

*1= not important at all, 7= very important 
Table 3: Beliefs about Purchasing From a Foreign Apparel Retailer

\begin{tabular}{|l|r|r|r|}
\hline \begin{tabular}{|l|r|r|}
\hline If I purchase from an foreign \\
apparel retailer, ......
\end{tabular} & $\mathrm{N}$ & Mean* & $\begin{array}{c}\text { Std. } \\
\text { Deviation }\end{array}$ \\
\hline I will have quality products. & 507 & 4,0394 & 2,00060 \\
\hline I will have fashionable products. & 506 & 4,1621 & 1,97945 \\
\hline I will have products which suit my style. & 505 & 4,6832 & 1,92586 \\
\hline I will have products which suit my size. & 505 & 4,8752 & 1,93605 \\
\hline I will find a wider product assortment. & 504 & 4,6468 & 1,84118 \\
\hline I will have better customer service. & 503 & 4,3738 & 1,94329 \\
\hline I will have more payment options & 505 & 4,0317 & 1,94645 \\
\hline I will shop in a good store layout. & 506 & 4,5020 & 1,82094 \\
\hline I will have attractive sales promotions. & 501 & 4,0519 & 1,88290 \\
\hline I will buy popular brand names. & 506 & 4,2984 & 2,02457 \\
\hline I will buy products with lower prices. & 505 & 3,1426 & 1,91575 \\
\hline I will shop in a place which is easy to access. & 504 & 3,8552 & 1,90866 \\
\hline
\end{tabular}

*1= strongly disagree, $7=$ strongly agree

Table 4: Attitude towards Purchasing From a Foreign Apparel Retailer

\begin{tabular}{|l|r|r|r|}
\hline & $N$ & Mean* & \multicolumn{1}{c|}{$\begin{array}{c}\text { Std. } \\
\text { Deviation }\end{array}$} \\
\hline Quality of products & 506 & 24,9427 & 14,21109 \\
\hline Fashionability of products & 504 & 21,4544 & 14,79959 \\
\hline Style & 503 & 29,6819 & 14,15686 \\
\hline Size & 503 & 31,9642 & 14,01091 \\
\hline Product assortment & 502 & 24,9024 & 13,66262 \\
\hline Customer service & 501 & 24,9601 & 14,05740 \\
\hline Number of payment options & 503 & 23,0199 & 13,97820 \\
\hline Organization of store layout & 500 & 22,7560 & 13,46339 \\
\hline Sales promotions & 494 & 22,7976 & 13,91045 \\
\hline Popular brand names & 501 & 19,2455 & 13,86584 \\
\hline Price of products & 503 & 18,8688 & 12,86378 \\
\hline Convenience of locations & 503 & 20,8032 & 13,32519 \\
\hline
\end{tabular}

*Mean scores could range between 1 and 49. 
Table 4 shows the attitudes of respondents towards buying from a foreign apparel retailer, based on the Fishbein model. Compatible with the previous results, the highest attitude score was related to size. This is reasonable because size was the attribute considered as the most important and had the highest belief score; i.e. respondents stated that they believed that by purchasing from a foreign apparel retailer, they would have clothes suitable for their sizes. This might indicate that foreign retailers are offering a wider range of sizes compared to domestic ones. A similar result was reported in as study conducted in Greece by Kamenidou et al. (2007: 150), where consumers of imported high fashion apparel appreciated the fit of these products. The quantitative study conducted by the same authors indicated that the main reasons for buying imported high fashion apparel were aesthetics of the apparels, the better "line" of these products; and the quality of textiles used to produce them (Kamenidou et al., 2007: 153). It may not be directly comparable to our market however since Greece is a geographically and culturally close country it might give some clues.

The attitude, which had the lowest score, was related to price. Price was considered quite important (Table 2) yet it had the lowest evaluation score. That means, although respondents care about price to a great extent, foreign retailers are not perceived as offering reasonable prices. The second lowest score was associated with popular brand names. This was the least important attribute, but the belief score was higher than 4 . In other words, respondents do not seem to care about popular brand names much, also they do not strongly agree that purchasing from a foreign apparel retailer would result in acquisition of popular brand names. This may be attributed to the fact that some of the foreign retailers are not familiar to Turkish consumers. Moreover many of them do not make advertisements and do not try to make themselves known. Another problem is that there are many domestic retailers with foreign names. So it is not easy for consumers to distinguish between foreign and domestic retailers.

Quality, which was seen to be one of the most important factors customers seek in their apparel purchases, did not get a high attitude score, which means foreign retailers are not perceived as good at reaching the quality standards Turkish customers expect. This is a very critical finding for international retailers.

\subsection{The Relationship between Age and Attitude towards Purchasing from Foreign Apparel Retailers}

In order to test the relationship between age and attitude towards purchasing from foreign apparel retailers, the authors conducted a correlation analysis between the overall attitude of respondents toward the relevant behavior and their ages. Overall attitude was found with the help of the formula, which is stated in the methodology section. That means, for each respondent, the overall attitude was calculated, by multiplying the evaluation score $\left(\mathrm{e}_{\mathrm{i}}\right)$, and the belief score $\left(b_{i}\right)$, and by summing the results for 12 attributes. As Table 5 demonstrates, there was a negative relationship between age and attitude. As 
age increases, attitude scores decreases or in other words, attitudes become more unfavorable. This finding supports most of the literature related to this subject (Anderson \& He, 1998; Ariga et. Al, 1997; Landry, 1998; Schmitt, 1997; Zhang et al., 2002; cited in Dickson et.al, 2004)

Table 5: Relationship between Age and Attitude towards Purchasing from Foreign Apparel Retailers

\begin{tabular}{|l|l|r|r|}
\hline $\begin{array}{l}\text { Overall } \\
\text { attitude }\end{array}$ & Pearson Correlation & $\begin{array}{r}\text { Overall } \\
\text { attitude }\end{array}$ & Age \\
\hline & Sig. (2-tailed) & 1 &,$- 160\left({ }^{* *}\right)$ \\
\hline & $\mathrm{N}$ & 457 &, 001 \\
\hline & Sig. (2-tailed) &, 001 & 452 \\
\hline & $\mathrm{N}$ & 452 & 500 \\
\hline
\end{tabular}

\subsection{The Effect of Foreign Country Visits on Attitude towards Purchasing from Foreign Apparel Retailers}

The effect of foreign country visits on the overall attitude was tested with oneway ANOVA, because visiting foreign countries was measured with a nominal scale. Hence, those who have visited foreign countries created one group and those who have not created the other group. As Table 6 shows, visiting foreign countries created a difference on attitudes. Those who have visited a foreign country have a higher attitude score where as those who have not had a lower score.

Table 6: Differences on Attitudes Created by Foreign Country Visits

\begin{tabular}{|l|r|rr|r|}
\hline Visit to foreign countries & & \\
\hline & Those who have visited & $\begin{array}{l}\text { Those } \\
\text { visited }\end{array}$ & who have not & \\
\hline Attitude & Mean & & Mean & $F$ \\
\hline
\end{tabular}
$p<0.10$

\section{CONCLUSION}

Apparel purchasing constitutes an important part of the overall purchases of consumers. So, it is important to get a deeper understanding of what consumers care about in choosing the apparel retailers that they will become patrons of. Thus in this study we investigated the attitudes towards purchasing from foreign apparel retailers on 507 respondents. Most of the respondents were between 21 
and 40 years old, perceived themselves to be in the middle income group and had highereducation. It is seen that all of the attributes considered were quite important for the participants, though the most important attributes turned out to be size, style, and quality respectively. The least important ones, on the other hand, are popular brand names, fashionability and store layout, respectively. It should be noted that these three attributes had only slightly lower scores than the rest, which makes them "relatively unimportant" instead of "unimportant".

Based on Fishbein Model the results of importance scale were also interpreted with the belief scale. In the belief scale, respondents declared the extent to which they agree that purchasing from foreign apparel retailers provides them with the attributes, which are taken into account when purchasing clothing. Belief scores, (all of which are lower than 5), indicate that the attributes, to which respondents attach importance, are not provided by foreign apparel retailers, at least not to a great extent. Pricing and convenience of location factors had the lowest belief scores. Probably, the prices of these retailers are perceived high by the respondents or they do not believe that they get the value for money they pay. Also quality is seen as another problem of foreign retailers. Convenience of location also had one of the lowest scores. In Izmir, foreign apparel retailers are usually found either in the high-end business district of Alsancak or in shopping malls. These shopping malls differ in their level of accessibility and usually require a car drive, because public transport is not possible to some of these places.

The highest belief scores for foreign retailers were pertained to size followed by style and product assortment. However, it should be kept in mind that again the scores were lower than 5 . The reason why sizes offered seem to be appreciated might be that, foreign chains like Marks and Spencer, Evans and C\&A are offering sizes addressed to consumers of larger sizes. Style was also one attribute that was appreciated by the respondents in foreign retailers. Respondents seem to believe that by purchasing from foreign apparel retailers; they find a wider product assortment. These findings also support the literature (Kamenidou et al., 2007: 153). Usually, international apparel retailers change their product assortment quite frequently (Zara and other retailers of Inditex Group). It is possible to see new products nearly each week. This should be the result of their power and capacity.

Overall the most favorable attitude was related to size, which was the most important attribute and had the highest belief score. That means, respondents believed that by purchasing from a foreign apparel retailer, they would have clothes suitable for their sizes. Style was the second most favorable attitude item. Perhaps size and style may be a basis for competitive advantage for foreign apparel retailers. Domestic apparel retailers should also reconsider their size alternatives. In Turkey, usually it is a problem for larger sized people to find suitable clothes from mainstream retailers, especially stylish ones. 
On the other hand, the lowest attitude scores were related to price and popular brand names. Price was considered quite important but had the lowest belief score. Although respondents care about price to a great extent, foreign retailers are not perceived as offering reasonable prices. Also, respondents do not seem to care about popular brand names. Nor do they strongly agree that purchasing from a foreign apparel retailer would result in ownership of popular brand names. This may be attributed to the fact that some of the foreign retailers are not known to Turkish consumers. Moreover they generally do not make advertisements and do not try to make themselves known. Another problem is that there are many domestic retailers with foreign names. So it is not easy for consumers to distinguish between foreign and domestic retailers. A very critical finding for foreign retailers is that foreign retailers are not good at reaching the quality standards that Turkish customers expect. So the attributes, which were considered as important but not believed to be provided by foreign retailers to a great extent, like price and quality should be improved. The prices should be either lower or higher but justified by a certain level of quality.

It was found that as age increases, attitude scores decrease or in other words, attitudes become more unfavorable. Hence, these retailers may address their marketing efforts at young generation, because they have a more favorable attitude toward purchasing from them compared to the elderly. In Turkey, after 1980 s the country was more open to international markets than before. Members of the young generation of today, who were children in 1980s, have always had exposure to imported goods. Moreover, they are more exposed to international culture by movies and the Internet. Hence, we have to distinguish between age and generation factor, because, as today's youth gets older, they may continue to have positive attitudes towards foreign apparel retailers. Thus, if international retailers attract today's young generation it is likely they also retain future adults.

Foreign country visits also created a difference on attitudes. Those who have visited a foreign country have a higher attitude score whereas those who have not had a lower score. The growing tourism sector and international business increased the chances of people to be exposed to the international retailers and get familiar with them. Hence foreign apparel retailers should consider that people do not just see them in the domestic market but also has the chance to visit those stores in countries they visit. So under that circumstance, retailers should understand that their company image must be consistent across countries to create a unique and believable image across the world.

The study was conducted only in Izmir and hence may not reflect the attitudes towards purchasing from foreign apparel retailers in Turkey. The replication of this study may be conducted in Istanbul or Ankara, which would help to gain a deeper understanding. Other demographic factors like income could influence consumers' views and may be examined in further research. 


\section{REFERENCES}

Allport, G. W. (1967), "Attitudes. Readings in Attitude Theory and Measurement”, Fishbein, M. (Ed.). John Wiley \& Sons, Inc., New York.

Anderson, P. and He, X. (1998), "Price influence and age segments of Beijing consumers", Journal of Consumer Marketing, Vol. 15 No. 2, pp. 152-69.

Ariga, M., Yasue, M. and Wen, G. (1997), "China's generation III: viable target segment and implications for marketing communications", Marketing and Research Today, Vol. 25

Beaudoin, Pierre, Mary Ann Moore and Ronald E. Goldsmith (1998), "Young Fashion Leaders' and Followers' Attitudes toward American and Imported Apparel", Journal of Product and Brand Management, 7, 3, p.193-207.

Bilkey, Warren and E. Nes (1982), "Country of Origin Effects on Product Evaluations", Journal of International Business Studies, 13, 1, s.89-99.

Buzzell, Robert D. (1968), "Can You Standardize Multinational Marketing?", Harvard Business Review, 46, 6, s.102-113.

Chowdhary, U. (1989), "Fashion Information Seeking by Younger and Older Consumers" Clothing and Textiles Research Journal, 8, s. 49-55.

De Mooij, Marieke and Geert Hofstede (2002), "Convergence and Divergence in Consumer Behavior: Implications for International Retailing", Journal of Retailing, 78, s.61-69.

Dickson, Marsha A., Sharron J. Lennon, Catherine P. Montalto, Dong Shen and Li Zhang (2003), "Chinese Consumer Market Segments for Foreign Apparel Products", Journal of Consumer Marketing, 21, 5, p.301-317.

Evans, Jodie and Kerrie Bridson (2005), "Explaining Retail Offer Adaptation through Psychic Distance", International Journal of Retail \& Distribution Management, 33, 1, s. 69-78.

Fishbein, M. 1967, "Readings in Attitude Theory and Measurement", John Wiley \& Sons, Inc., New York.

Fishbein, M. 1980, "An Overview of the Attitude Construct. A Look Back, a Look Ahead", G. B. Hafer (ed.), American Marketing Association, Chicago.

Fishbein, M., I. Ajzen 1975, "Belief, Attitude, Intention and Behavior: An Introduction to Theory and Research", Addison-Wesley Publishing Company, United States of America. 
Hyllegard, Karen, Molly Eckman, Alejandro Molla Descals and Miguel Angel Gomez Borja (2005), 'Spanish Consumers' Perceptions of US Apparel Specialty Retailers' Products and Services”, Journal of Consumer Behavior, 4, 5, p.345-362.

Kamenidou, Irene, John Mylonakis and Konstantina Nikolouli (2007), "An Exploratory Study on the Reasons for Purchasing Imported High Fashion Apparel: The Case of Greece", Journal of Fashion Marketing and Management, 11,1, p.148-160.

Kompil, Mert and H. Murat Çelik (2006), "Analyzing the Retail Structure Change of Izmir-Turkey: Integrative and Disintegrative Aspects of Large-Scale Retail Developments", $42^{\text {nd }}$ ISOCARP Congress, Yildiz Technical University, Turkey, www.isocarp.net/Data/case_studies/785.pdf [Access February 12, 2008].

Kwambata, Hiroko and Nancy J. Rabolt (1999), "Comparison of Clothing Purchase Behaviour between US and Japanese Female University Students", Journal of Consumer Studies \& Home Economics, 23, 4, s.213-223.

Landry, J.T. (1998), "Are Chinese consumers coming of age?”, Harvard Business Review, 76, 3, s. 17-18.

Levitt, Theodore (1983), "The Globalization of Markets", Harvard Business Review, 61, 3, s.92-102.

Lindquist, Jay D. (1974-75) "Meaning of Image", Journal of Retailing, 50, 4, s.29-38

Lumpkin, J.R., Greenberg, B.A. (1982), "Apparel-shopping patterns of the elderly consumer", Journal of Retailing, 58, s.68-89.

Lumpkin. J.R. (1984), "The effect of retirement versus age on the shopping orientations of the older consumer", The Gerontologist, 24, 6, s. 622-627.

Mason, J.B., Bearden, W.O. (1978), "Profiling the shopping behavior of elderly consumers", The Gerontologist, 18, 5, s. 454-461.

Moore, Marguerite and Ann Fairhurst (2003), "Marketing Capabilities and Firm Performance in Fashion Retailing", Journal of Fashion Marketing and Management, 7, 4, s.386-397.

Moye, Letecia N. and Doris H. Kincade (1999) "Shopping Orientation Segments: Exploring Differences in Store Patronage and Attitudes toward Retail Store Environments among Female Apparel Consumers", International Journal of Consumer Studies, 27, 1, s.58-71.

Parameswaran, R. and R.M. Pisharodi (1994), "Facets of Country-Of-Origin Image: An Empirical Assessment”, Journal of Advertising, 23, 1, s.43-56. 
Paulins, V. Ann and Loren V. Geistfeld (2003), "The Effect of Consumer Perceptions of Store Attributes on Apparel Store Preference", Journal of Fashion Marketing and Management, 7, 4, s.371-385.

Pessemier, E.A. (1980), "Store image and positioning", Journal of Retailing, 56, 94-106.

Peter, J.P. and J.C. Olson (1987), "Consumer Behavior: Marketing Strategy Perspectives", Irwin, Illinois.

Peterson, R. and A. Jolibert (1995), "A Meta-Analysis of Country-Of-Origin Effects", Journal of International Business Studies, 26, 4, s.157-75.

Phau, I. and Y.S. Leng (2008), "Attitudes toward Domestic and Foreign Luxury Brand Apparel: A Comparison between Status and Non Status Seeking Teenagers", Journal of Fashion Marketing and Management, 12, 1, s.68-89.

Piron, F. (2000), "Consumers' Perceptions of The Country-of-Origin Effect on Purchasing Intentions of (In)Conspicuous Products", Journal of Consumer Marketing, 17, 4/5, s.308-28.

Retailing in Turkey (2004). Euromonitor.

http://www.gmid.euromonitor.com/Reports.aspx, Accessed 20.06.2006

Scarpi, Daniele (2006), "Fashion Stores between Fun and Usefulness", Journal of Fashion Marketing and Management, 10, 1, p.7-24.

Schmitt, B. (1997), "Who is the Chinese consumer? Segmentation in the People's Republic of China", European Management Journal, Vol. 13 No.2, s.191-4.

Stone, G.P. (1954), "City shoppers and urban identification: observations on the social psychology of city life", The American Journal of Sociology, July, 36-45

Tek, Ömer Baybars and Fatma Demirci Orel (2006), "Perakende Pazarlama Yönetimi”, Birleşik Matbaaclık, Izmir.

Tokatl, Nebahat and Yonca Boyacı (1998), "The Changing Retail Industry and Retail Landscapes: The Case of Post-1980 Turkey”, Cities, 15, 5, s.345-359.

Udell, J.G. 1971, "Can Attitude Measurement Predict Consumer Behavior? Consumer Behavior: Contemporary Research in Action", Holloway, R. J., Mittelstaedt, R. A., Venkatesan, M. (ed.), Houghton Mifflin Company, Boston, $140-148$

Vida, Irena and Ann Fairhurst A. (1998), "International Expansion of Retail Firms: A Theoretical Approach for Future Investigations", Journal of Retailing and Consumer Services, 5, 3, s.143-151. 
Vijayasarathy, L. R. and J. M. Jones (2000), "Intentions to Shop Using Internet Catalogues: Exploring the Effects of Product Types, Shopping Orientations and Attitudes Toward Computer", Electronic Markets, 10, s.29-38.

Wang, Yun and Jeanne Heitmeyer (2006), "Consumer Attitude toward US versus Domestic Apparel in Taiwan", International Journal of Consumer Studies, 30, 1, s.64-74.

White, Darin W. and Keith Absher (2007), "Positioning of Retail Stores in Central and Eastern European Accession States: Standardization versus Adaptation", European Journal of Marketing, 41, 3/4, s.292-306.

Yalch, R. and Spangenberg, E. (1993), ' Using store music for retail zoning: a field. experiment", Advances in Consumer Research, . 20, s. 632-6.

Zhang, Z., Li, Y., Gong, C. and Wu, H. (2002b), "Casual wear product attributes: a Chinese consumers' perspective", Journal of Fashion Marketing and Management, 6, 1, s. 53-62.

Visvabharathy, G. and Rink, D.R. (1985), "The elderly: stil the 'invisible and forgotten' market segment", Journal of the Academy of Marketing Science, 13, 4, s. $81-100$

Lumpkin, J.R. (1985), "Shopping orientation segmentation of the elderly consumer", Journal of the Academy of Marketing Science, 13, 2, s. 271-289. 